\title{
WS1-6
}

\section{Microsurgical epididymovasostomy}

神戸大学 医学部 泌尿器科

稲葉洋子

閉塞性無精子症は精路再建が成功すれば精液所見は正常化し、自然妊娠も可能である。このことは言い換えれば、 治療における技術的要素の重要性を意味する。しかしながら、手術統計（松田ら 日本不妊学会誌 $45: 143-149$ 2000）からも明らかなとおり、精路再建は施行可能な施設が限られており、その実施件数もごく少数である。すな わち、手術療法によって治療可能な数多くの症例が不要な生殖補助技術の適応とされているのが現状である。本ビ デオセッションでは、精路再建術の中でも比較的難易度の高い精巣上体管精管吻合術について、演者らが行ってい る術式のポイントについて解説する。精路再建術の普及の一助とできれば幸いである。最後に、精管精管吻合術を 行う際に、肉眼あるいはルーペを用いた一層縫合でも可能であるが、強拡大視野での手術操作を必要とする精巣上. 体管精管吻合術をいきなり行うのは困難である。日ごろから顕微鏡下二層縫合で精管精管吻合術を行い、手術用顕 微鏡の操作に慣れておくことが肝要であることを強調したい。

\section{WS1-7}

\section{射精管開放術}

関西医科大学 泌尿器科

六車光英, 日浦義仁, 室田卓之, 川村 博, 松田公志

【目的】射精管閉塞は男性不妊症の原因として比較的稀であるが, 経尿道的手術により妊孕性を回復できるので重要 である。 今回我々は midline cystによる射精管閉塞の 2 例に対して射精管開放術を行ったのでビデオで供覧する. 【症例 1】31 歳男性, 不妊を主訴に来院. 精液所見は精液量 $0.4 \mathrm{ml}$, 無精子症で, 経直腸エコーで前立腺の正中に露 胞を認めた. 精管造影で精管末端に囊胞が造影され, 膀胱鏡で前立腺部尿道の 6 時方向に隆起を認めた。この隆起 を経尿道的に cold knife で切開し, 露胞の開放を行ったところ, 精液所見は術後 7 ヶ月で精液量 $1.5 \mathrm{ml}$, 精子濃度 4350 万 $/ \mathrm{ml}$, 運動率 $49 \%$ に改善し, 術後 5 年で自然妊娠し, 正常女児を得た.【症例 2】24 歳未婚男性, 血尿・血精 液症を主訴に来院. 経直腸エコーで前立腺正中に露胞を認め, 膀胱鏡で前立腺部尿道の 6 時方向に隆起を認めた. 精液所見は精液量 $5.2 \mathrm{ml}$, 精子濃度 490 万/ml, 運動率 $1 \%$ であった. 部分的射精管閉塞と考え, 経尿道的切除によ る蘘胞の開放を行ったところ, 術後 3 ヶ月で精液所見は精液量 $9 \mathrm{ml}$, 精子濃度 1800 万 $/ \mathrm{ml}$, 運動率 $33 \%$ に改善し た.【考察】経直腸エコーの進歩および部分閉塞の概念の確立により射精管閉塞の頻度は以前思われていたよりも高 いと考えられる. 射精管閉塞に対する経尿道的切除術の治療成績は比較的良好なので, 男性不妊症では射精管閉塞 も考慮して適切に診断・治療を行う必要がある.【文献】六車ほか：Midline Cystによる射精管閉塞の 2 例. 日不妊 会誌 $46: 203$-207,2001 